\title{
Differential Flotation of Some Egyptian Feldspars for Separation of Both Silica and Iron Oxides Contaminants
}

\author{
Tawfik Refaat Boulos, Suzan Sami Ibrahim, Ahmed Yehia \\ Central Metallurgical Research \& Development Institute (CMRDI), Cairo, Egypt \\ Email: secretary_cmrdi@hotmail.com
}

Received 24 September 2015; accepted 2 November 2015; published 5 November 2015

Copyright @ 2015 by authors and Scientific Research Publishing Inc.

This work is licensed under the Creative Commons Attribution International License (CC BY).

http://creativecommons.org/licenses/by/4.0/

(c)

\begin{abstract}
An anionic-cationic flotation of two Egyptian feldspar samples, representing Road Ashaab locality of the Eastern Desert of Egypt, was investigated on both laboratory and pilot plant scales. The pegmatites belong to the alkali feldspar granite type, mostly microcline and orthoclase, $\mathrm{KAL} \mathrm{Si}_{3} \mathrm{O}_{8}$ coarse grained rocks. Quartz, as the main gangue mineral, occurs in two forms as either free grains or as veins intercalating the feldspar crystals or, sometimes, intermingled with them. Iron, on the other hand, is found in three different forms as free magnetite embedded in the feldspar crystals, as microcrystalline crystals, or as magnetite filling cracks in the feldspar. Dissolution of magnetite to hematite is, sometimes, observed. Grinding of the feldspar samples to less than $0.25 \mathbf{~ m m}$ followed by desliming was optimized in the laboratory, using a ball mill in closed circuit with the screen. Anionic flotation of the iron oxide impurity from the $-0.25+0.03 \mathrm{~mm}$ ground product was successfully conducted using locally produced dodecyl benzene sulphonic acid-rice bran oil/kerosene promoter at $\mathrm{pH} 3$. Cationic flotation of feldspar from this product was then carried out employing a locally produced quaternary ammonium salt in presence of $\mathrm{HF}$ acid, as a silica depressant and a feldspar activator at $\mathrm{pH}$ 3. Feldspar final concentrates assaying $80.8 \% \mathbf{- 8 9 . 5 \%}$ feldspar mineral, $0.119 \%-0.127 \% \mathrm{Fe}_{2} \mathrm{O}_{3}$ and $16.84 \%-18.65 \% \mathrm{Al}_{2} \mathrm{O}_{3}$, were obtained at the optimum operating conditions that satisfy the requirements of the ceramic industry. Continuous $200 \mathrm{~kg} / \mathrm{h}$ pilot plant runs were conducted using the appropriate equipment, based upon the laboratory findings to produce feldspar concentrates assaying $16.38 \%-18.13 \% \mathrm{Al}_{2} \mathrm{O}_{3}$, and $0.13 \%-0.15 \% \mathrm{Fe}_{2} \mathrm{O}_{3}$. $\mathrm{Ma}^{-}$ terials' metallurgical balance and complete chemical analyses were shown.
\end{abstract}

\section{Keywords}

Na-Feldspar, K-Feldspar, Flotation, Sand Separation, Effect of pH

How to cite this paper: Boulos, T.R., Ibrahim, S.S. and Yehia, A. (2015) Differential Flotation of Some Egyptian Feldspars for Separation of Both Silica and Iron Oxides Contaminants. Journal of Minerals and Materials Characterization and Engineering, 3, 435-443. http://dx.doi.org/10.4236/immce.2015.36046 


\section{Introduction}

Feldspars are indispensable raw materials for many industries, such as ceramics, glass and fillers for plastics production. Considerable reserves of feldspar varieties are found in the Eastern Desert of Egypt, most of which are used as it is without processing.

The development of a satisfactory concentration process of feldspar depends not only upon its separation but also upon the maintenance of a proper size ratio of feldspar particles that satisfy the trade requirements [1]. The specification of size ranges from as coarse as $-0.75 \mathrm{~mm}+0.15 \mathrm{~mm}$ to a size as fine as $-0.075 \mathrm{~mm}$. Various methods of separation, such as differential grinding and sizing, gravity concentration, electrostatic separation and flotation had been developed in the past [1]-[4]. Each process had been partly successful or had failed because of unsuitability of the size range or lack of selectivity.

Recently, the ability to beneficiate feldspar has developed remarkably because flotation techniques proved its viability [2] [4] [5]. It is now possible to free feldspar from all kinds of gangue minerals, e.g. mica, quartz and heavy minerals in addition to separation of both $\mathrm{K}$ and $\mathrm{Na}$ feldspars from each other [2]-[4]. Cationic flotation of feldspar (amine + HF) in presence of $\mathrm{NaCl}$ was conducted by CengizDemir of Turkey in 2010 to separate both Na- and K-feldspar [3]. NaCl addition controls amine adsorption on sodium feldspar through adsorption of $\mathrm{Na}+$ ions onto the mineral surface [3]. The use of $\mathrm{NaCl}$ addition in flotation was found to increase the K-feldspar grade in the concentrate.

The flotation behavior of feldspars is essentially determined by their surface condition and thus by the extent of hydrolytic decomposition of feldspar surfaces [6]. The cationic-type collectors, which are most satisfactory for acidic minerals, were used in the flotation of feldspars in the thirties. In 1982, it was found that $\mathrm{C}_{6-14}$ primary amine hydrochloride collectors were used for the flotation of feldspars in presence of HF or a mixture of $\mathrm{HF}$ and $\mathrm{NaCl}$. The $\mathrm{C}_{10-12}$ amine gave the best flotation results [7] [8]. The feldspar was activated whereas the quartz was depressed by conditioning with HF. A comprehensive review on flotation of mica, iron oxides, ilmenite and other gangue minerals from feldspar was discussed by Heyes et al. in 2012 [9].

However, a HF-free flotation process using a mixture of the cationic and anionic collectors for the separation of feldspar from sand was described by Katayanagi [4] and the process was reported to be applied in industrial practice [2] [4]. In an aqueous medium the feldspar surface shows, after a short time, changes which have a negative effect on floatability. Therefore, the residence times during reagent conditioning and during flotation too should be as short as possible [7] [10]. Referring to the fact that in HF-containing pulps, a considerable amount of the Fe ions of the mineral surface dissolves and then forms bond with F ions, so iron-rich minerals should be eliminated as much as possible prior to flotation [11] [12].

In this respect, the present investigation is a "step-on-the-road" for better quality Egyptian feldspars.

\section{Experimental Techniques}

\subsection{Laboratory Beneficiation Tests}

The feldspar samples were crushed in a "Denver" pilot jaw crusher followed by a "Wedag" roller in closed circuit with $3.5 \mathrm{~mm}$ screen. The $-3.5 \mathrm{~mm}$ crushed products were mixed thoroughly, then quartered by a "Jones" sampler to about $3 \mathrm{~kg}$ batches. One of these batches was finely ground to $100 \%$ less than $74 \mu \mathrm{m}$ for complete chemical analysis. On the other hand, mineralogical examination of the samples was carried out on hand-picked thin and polished sections.

The flotation feed samples were prepared by grinding the secondary crushed ores to $100 \%$ less than $0.25 \mathrm{~mm}$ in a rod mill in closed circuit with the screen, under the predetermined optimum conditions. The ground products were then screened on $0.1 \mathrm{~mm}$ sieve and the undersize products were deslimed using a "Mozley" portable 3" hydrocyclone to remove the $-30 \mu \mathrm{m}$ slimes at a feed pressure of $20 \mathrm{psi}$ and $15 \%$ pulp density. The cyclone underflow products were thoroughly mixed with the $-0.25+0.1 \mathrm{~mm}$ size fraction. The dried products were sampled to $300 \mathrm{~g}$ batches for the flotation tests. In this respect, a "Denver D 12" flotation cell was used which is a simulation of the sub-aeration type.

\subsection{Reverse Anionic Flotation of Iron Oxides Contaminants}

Dodecyl benzene sulphonic acid was used as a collector without or with the addition of rice bran oil as a foam regulator. This is an Egyptian by-product of the rice industry which proved its viability for such purpose. The 
former was added as a $10 \%$ solution and the latter was diluted with kerosene in 1:1 mixture by volume. Factors affecting the process were verified under $\mathrm{pH} 3$ using $\mathrm{H}_{2} \mathrm{SO}_{4}$. These included the collector dose, the effect of adding rice bran oil, pulp $\mathrm{pH}$, and the effect of using coarser size flotation feed.

\subsection{Direct Cationic Flotation of Feldspar}

Locally produced quaternary ammonium salt was used to separate the silica impurities from the previously obtained flotation concentrate. Hydrofluoric acid was added in this circuit as a silica depressant and a feldspar activator as well. Optimization of the process was carried out under the following operating parameters: $\mathrm{pH} 3$, dose of dodecyl benzene sulphonic acid/rice bran oil/kerosene blend of 1.5:0.75:0.75 kg/t.

\subsection{Pilot Plant Production of Feldspar Concentrates}

Figure 1 depicts the beneficiation flowsheet and layout of equipment. In the first part of the circuit, the -3.5 crushed ore was wet ground to $-0.25 \mathrm{~mm}$ in a $24 \times 16$ " "Denver" rod mill in a closed circuit with a 9" spiral classifier. A pulp density of $50 \%$ solid and a residence time of $12 \mathrm{~min}$. were always maintained in the mill, Figure 1. The classifier overflow product, O.F., was delivered to another spiral classifier for removal of the -0.03 $\mathrm{mm}$ slimes whereas the $-0.25+0.03 \mathrm{~mm}$ underflow, U.F., product was directed towards the conditioning tank.

The anionic collector, dodecyl benzene sulphonic acid/rice bran oil in kerosene mixture (1.5:0.75:0.75 kg/t) was added to the tank with close control of the $\mathrm{pH}$ at 2.5 - 3 and the pulp density at about $50 \%$ solid, and conditioning time $3 \mathrm{~min}$. The conditioned pulp was then directed to a 6-flotation cell bank where roughing and cleaning processes were carried out in the first four units only. The iron oxides froth was sent to dump whereas the sink (feldspar) was pumped to "Denver" attrition scrubber for surface cleaning. De-oiling of the product was then performed in a "Denver" hydrosizer, the O.F. of which was dumped whereas the thickened feldspar pulp was delivered to another conditioning tank for addition of $\mathrm{HF}$ acid $(0.3 \mathrm{~kg} / \mathrm{t})$ as a free silica depressant at $\mathrm{pH} 2.5$ - 3. The conditioned pulp was then delivered to the last two flotation cell units, for direct flotation of feldspar after the addition of the amine cationic collector at a rate of $0.3 \mathrm{~kg} / \mathrm{t}$ in the rougher cell. The cleaner feldspar concentrate was then collected as the final product from the last flotation cell whereas the depressed free silica was sent to dump.

Continuous pilot plant runs were carried out with both feldspar samples at a feed rate of $200 \mathrm{~kg} / \mathrm{h}$ with close control of all parameters. Samples were collected periodically from feed and all outlets for metallurgical balance calculations.

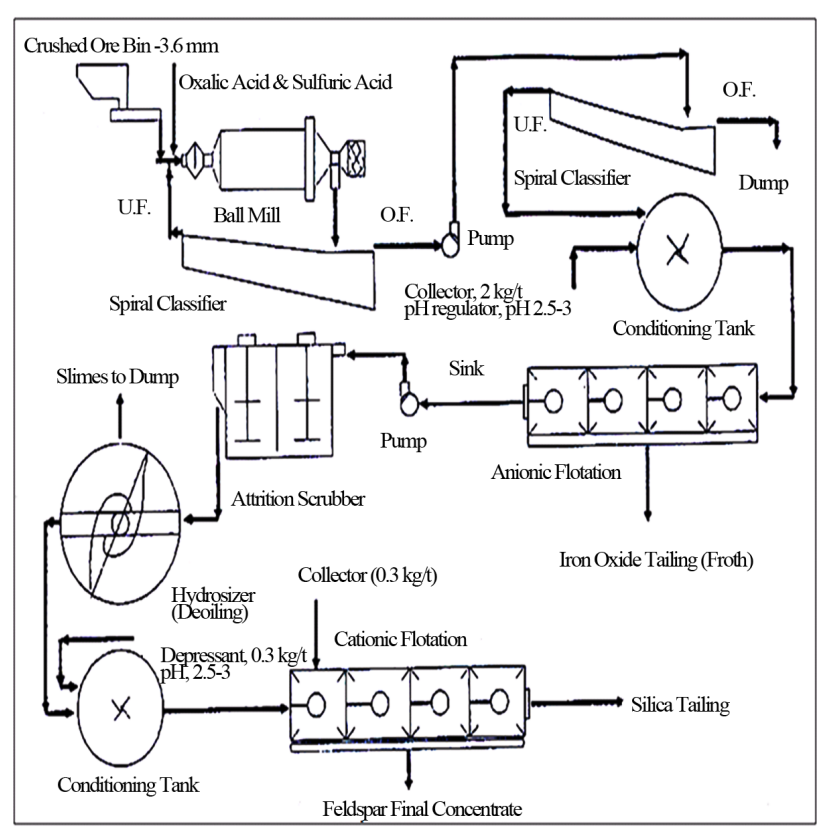

Figure 1. The Feldspar beneficiation flow-sheet and equipment layout. 


\section{Results and Discussion}

\subsection{Characterization of the Feldspar Samples}

Complete chemical analyses of the feldspar samples, shown in Table 1, indicate that they belong to the alkali-feldspar granite type, highly siliceous, rich in $\mathrm{Al}_{2} \mathrm{O}_{3}$ and $\mathrm{K}_{2} \mathrm{O}$, but poor in $\mathrm{Fe}_{2} \mathrm{O}_{3}$ and $\mathrm{MgO}$.

Mineralogically the pegmatites are coarse grained rocks, crystals may reach one centimeter to decimeter in size. The most abundant feldspar minerals are microcline, $\mathrm{KAlSi}_{3} \mathrm{O}_{8}$. It occurs in large crystals showing cross hatching lamellar twinning, Plate 1(a). Orthoclase is the second feldspar mineral, $\mathrm{KAlS}_{3} \mathrm{O}_{8}$ that was identified with its twinned forms, e.g. carlsbad, baveno and manebach, Plate 1(b). Both minerals are found associated with each other, Plate 1(b). Quartz occurs in two forms: as free grains, Plate 1(c) and as veins intercalating the feldspar crystals, or sometimes, intermingled with them, Plate 1(d). Iron, on the other hand, is found in three different forms; in free magnetite crystals embedded in the feldspar as microcrystalline crystals, Plate $1(\mathrm{e})$ or filling cracks in the feldspar, Plate 1(f). The size of the different mineral species varies between $1 \mathrm{~mm}$ to $3 \mathrm{~mm}$. The pegmatitic rocks form, sometimes, perthitic plates with quartz, a property that may help rock pulverization and facilitates the degree of minerals liberation.

\subsection{Optimization of the Differential Flotation Process}

Fine grinding of the pulverized feldspar samples to $100 \%$ less than $0.25 \mathrm{~mm}$ in the rod mill accompanied with proper desliming was a perquisite to flotation. Results show that only $6.26 \%$ by weight of the ground product was lost in the $-0.03 \mathrm{~mm}$ slimes but it was overloaded with iron oxide reaching about $2 \%$. The accumulation of this iron oxide in the O.F. of the cyclone may be due to the surface coating of the feldspar grains with a ferruginous clayey matrix which was disintegrated by the feed pressure of the hydrocyclone.

\subsubsection{Anionic Flotation of Iron Oxides}

Results illustrated in Figure 2 show a successive decrease in the $\% \mathrm{Fe}_{2} \mathrm{O}_{3}$ of the feldspar pre-concentrate from $0.39 \%$ to $0.18 \%$ by using $9 \mathrm{~kg} / \mathrm{t}$ of dodecyl benzene sulphonic acid collector. By stepwise addition of the collector in $2 \mathrm{~kg} / \mathrm{t}$ each, this could be cut down to $7 \mathrm{~kg} / \mathrm{t}$ only. Nevertheless, this is a rather high consumption of a reagent, in addition to its questionable highly stable form in the flotation cell (specially tailored for the detergency industry.

By addition of rice bran oil as a foam regulator, results shown in Table 2 indicate that in addition to that, a drastic drop in the collector consumption to $1.5 \mathrm{~kg} / \mathrm{t}$ was achieved by blending with the rice bran oil/kerosene mixture of $0.75 \mathrm{~kg} / \mathrm{t}$ each. A better quality concentrate was obtained having $0.18 \% \mathrm{Fe}_{2} \mathrm{O}_{3}$ with a feldspar recovery of 73\%. Therefore the dodecyl benzene sulphonic acid/rice bran oil in kerosene blend of 2:1:1 1.5:0.75:0.75 $\mathrm{kg} / \mathrm{t}$ ) was chosen as the optimum.

The effect of changing pulp $\mathrm{pH}$ on the concentrate quality under the predetermined optimum conditions is illustrated in Figure 3. Evidently the best $\mathrm{pH}$ is around 3. At pH 4, the grade of the concentrate deteriorates, despite the loss in its weight due to flotation of the feldspar itself by increase in $\mathrm{pH}$.

Although the grain size requirement of feldspar employed in the ceramic industry is $98 \%$ by weight less than $74 \mathrm{~mm}$, yet relatively coarser size limits are compelled in the glass industry (up to $0.42 \mathrm{~mm}$ ). Table 3 shows that by using the $-0.417+0.02 \mathrm{~mm}$ relatively coarse size in feldspar flotation a relative increase in the yield of concentrate from $73 \%$ to $79.4 \%$ occurs, but this happens on the prejudice of product grade. The $\mathrm{Fe}_{2} \mathrm{O}_{3}$ content is

\begin{tabular}{ccc} 
Table 1. Complete chemical analysis of feldspar samples. & \\
\hline Constituent & Sample I \% & Sample II \% \\
\hline Total SiO$_{2}$ & 72.37 & 73.50 \\
$\mathrm{Al}_{2} \mathrm{O}_{3}$ & 11.97 & 12.50 \\
$\mathrm{Fe}_{2} \mathrm{O}_{3}$ & 0.53 & 0.22 \\
$\mathrm{Na}_{2} \mathrm{O}$ & 2.28 & 2.13 \\
$\mathrm{~K}_{2} \mathrm{O}$ & 8.38 & 9.30 \\
$\mathrm{MgO}$ & 0.25 & 0.23 \\
\hline
\end{tabular}




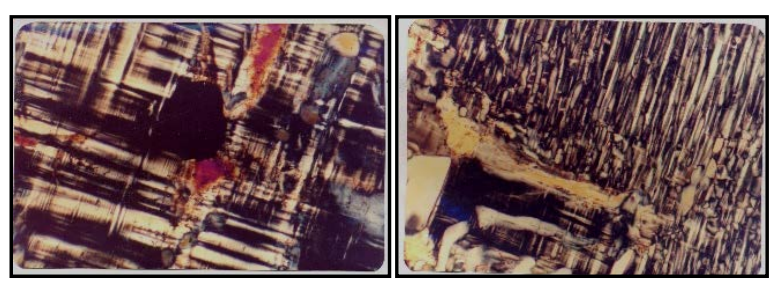

(a)
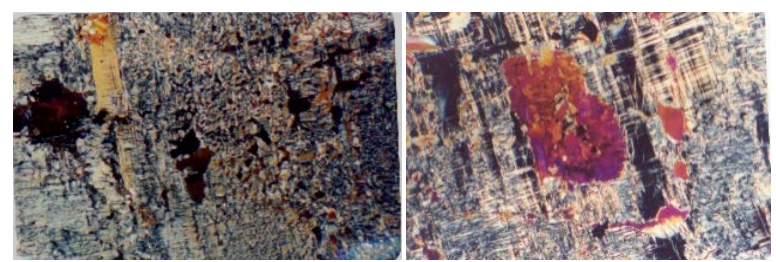

(b)

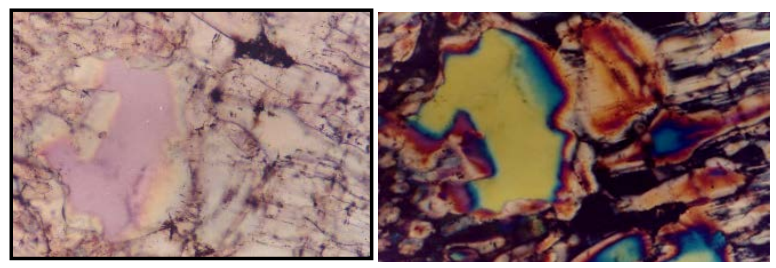

(c)

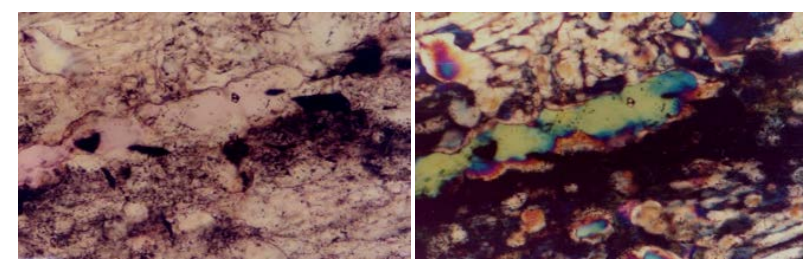

(d)

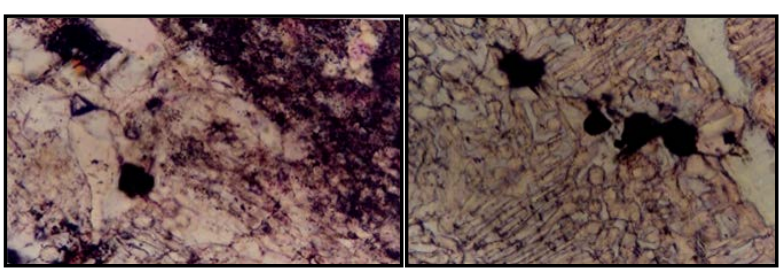

(e)

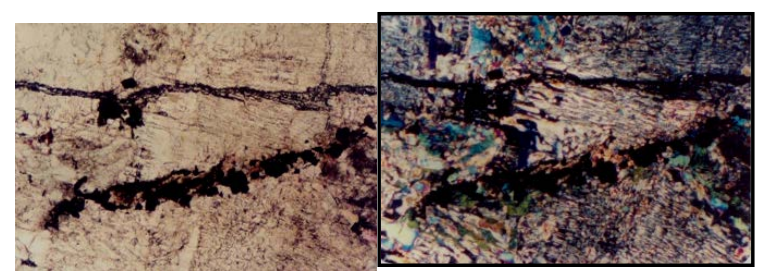

(f)

Plate 1. Petrography pictures of feldspar samples. (a) Large microcline crystals showing cross hatching lamellar twining, (XN, 500×); (b) Orthoclase crystals embedded in microcline, (XN, $100 \times$, and 500×, respectively); (c) Quartz grains embedded in a feldspar ground mass, (PPL, 500×, and XN, respectively); (d) Quartz vein cutting feldspar, magnetite crystals (Dark), (PPL, 500×); (e) Microcrystalline magnetite crystals embedded in feldspar, (PPL, 100×, and Magnetite crystals embedded (20 - 40 $\mu \mathrm{m}$ ) in feldspar ground mass, (PPL, 500×), respectively; (f) Magnetite crystals filling cracks in feldspars, (PPL, X 500, and in XN, respectively). 


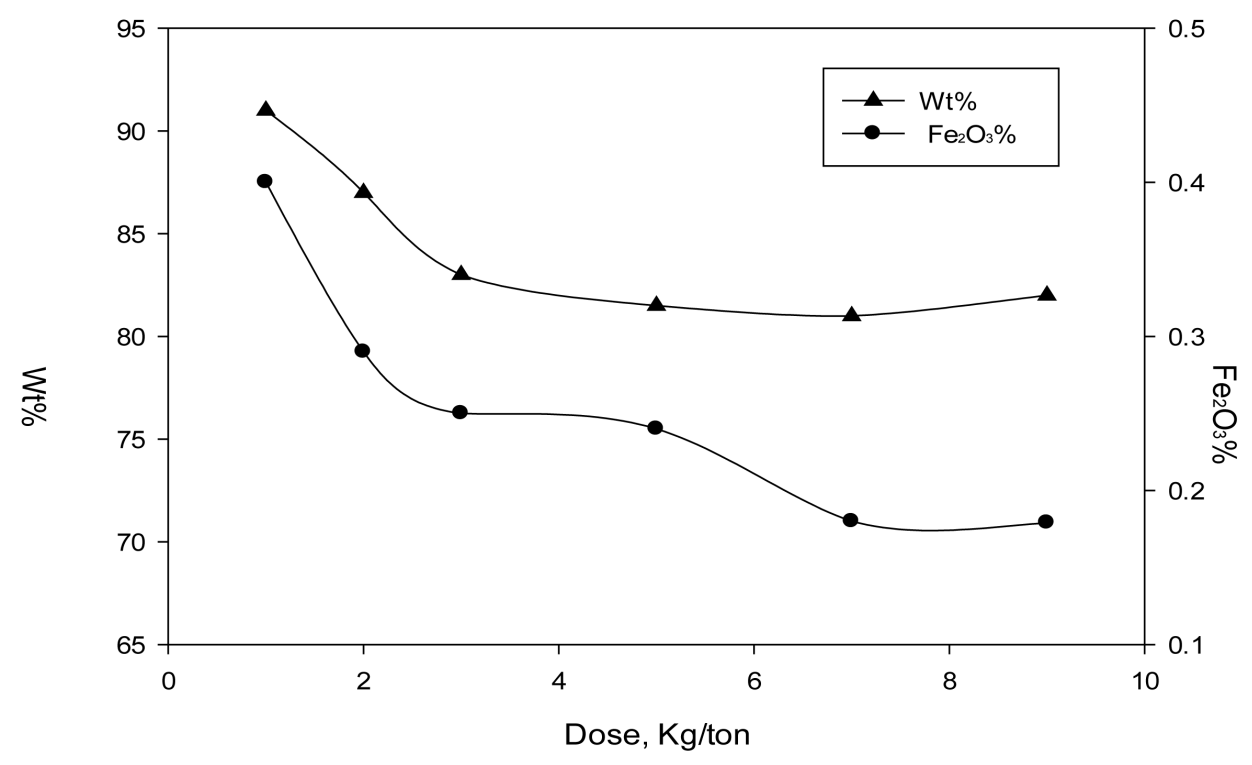

Figure 2. Effect of dodecyl benzene sulphonicacid dose.

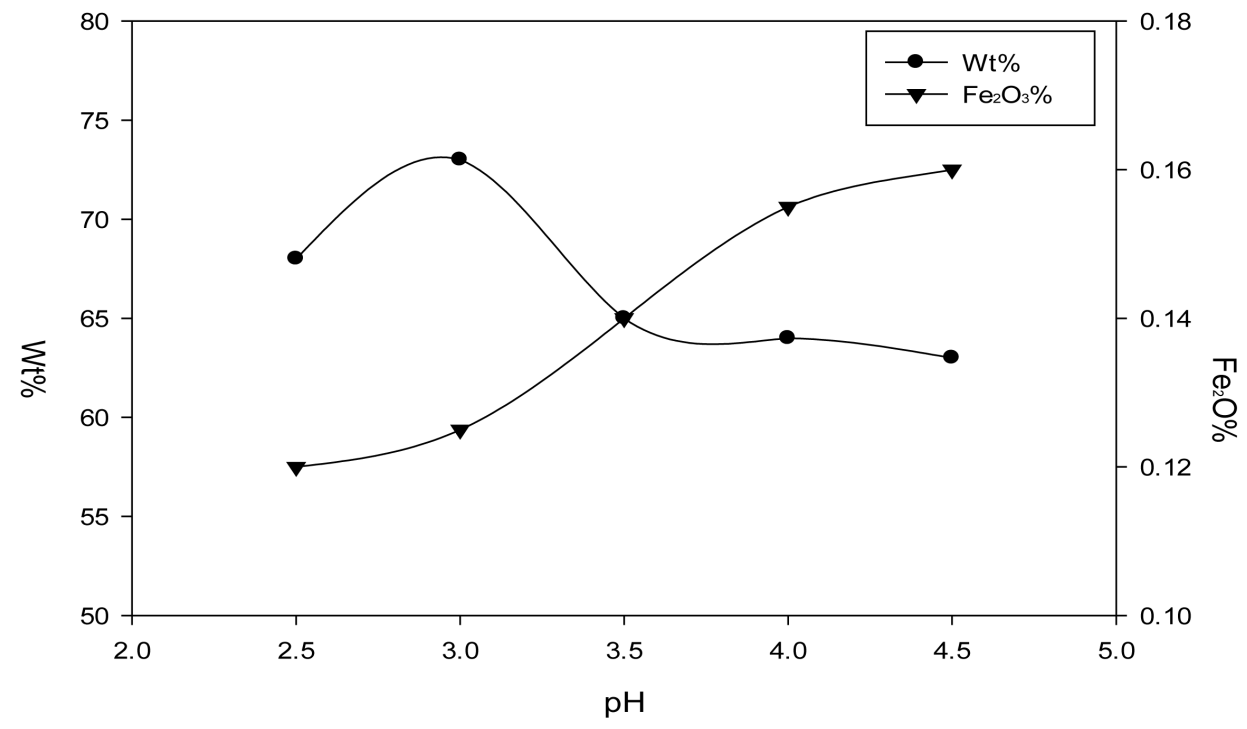

Figure 3. Effect of flotation pH on the concentrate quality of the anionic circuit.

doubled in this latter case (from $0.12 \%$ to $0.242 \%$ ).

\subsubsection{The Cationic Flotation of Feldspar}

When the feldspar pre-concentrate obtained under the predetermined optimum conditions was subjected to a differential cationic flotation process using the locally produced amine $(0.25 \mathrm{~kg} / \mathrm{t})$ in presence of HF acid $(1.3$ $\mathrm{kg} / \mathrm{t}$ ), the optimum $\mathrm{pH}$ was found between 2.5 and 3, Table 4. A concentrate assaying $75.86 \%$ feldspar, $15.3 \%$ $\mathrm{Al}_{2} \mathrm{O}_{3}$ and $0.12 \% \mathrm{Fe}_{2} \mathrm{O}_{3}$ was obtained with a total $\% \mathrm{SiO}_{2}$ of 65.91 .

By increasing the dose of the cationic collector under the optimum $\mathrm{pH}$ and in presence of HF acid, a relative improvement in the concentrate grade and recovery occurs at $0.291 \mathrm{~kg} / \mathrm{t}$ of the amine, Table 5 . Under such conditions, increasing the HF acid consumption successively leads to a pronounced increase in the concentrate grade in terms of both feldspar and $\mathrm{Al}_{2} \mathrm{O}_{3}$ content, Table 6. At a maximum dose of $5.20 \mathrm{~kg} / \mathrm{t}$ of $\mathrm{HF}$ acid, a concentrate assaying $18.65 \% \mathrm{Al}_{2} \mathrm{O}_{3}, 0.119 \% \mathrm{Fe}_{2} \mathrm{O}_{3}$ and $65.3 \%$ total $\mathrm{SiO}_{2}$ (89.52\% feldspar), Table 6. Complete chemical analysis of the two feldspar samples at optimum flotation conditions are illustrated in Table 7. 
Table 2. Effect of mixing the collector with rice bran oil.

\begin{tabular}{|c|c|c|c|c|c|}
\hline \multicolumn{3}{|c|}{ Dose, kg/ton } & \multirow{2}{*}{ Conc. Wt\% } & \multirow{2}{*}{$\mathrm{Fe}_{2} \mathrm{O}_{3} \%$} & \multirow{2}{*}{ Feldspar Rec. \% } \\
\hline Sulphonic acid & Rice Bran Oil & Kerosene & & & \\
\hline 3.00 & 0.00 & 0.0 & 80.48 & 0.262 & 59.45 \\
\hline 3.00 & 0.25 & 0.25 & 77.95 & 0.240 & 60.02 \\
\hline 3.00 & 0.5 & 0.5 & 70.89 & 0.166 & 77.37 \\
\hline 3.00 & 0.75 & 0.75 & 65.54 & 0.170 & 78.57 \\
\hline 1.50 & 0.75 & 0.75 & 72.98 & 0.120 & 83.16 \\
\hline 3.00 & -- & 1.5 & & No Fr & \\
\hline
\end{tabular}

Table 3. Effect of using coarser size fraction feed.

\begin{tabular}{ccc}
\hline Flotation Feed Size, $\mathrm{mm}$ & $\mathrm{Fe}_{2} \mathrm{O}_{3} \%$ & Yield \% \\
\hline$-0.25+0.020$ & 0.120 & 72.98 \\
$-0.417+0.02$ & 0.242 & 79.44 \\
\hline
\end{tabular}

Table 4. The effect of $\mathrm{pH}$ on the cationic flotation process.

\begin{tabular}{ccccc}
\hline $\mathrm{pH}$ & $\mathrm{Total} \mathrm{SiO}_{2} \%$ & $\mathrm{Al}_{2} \mathrm{O}_{3} \%$ & $\mathrm{Fe}_{2} \mathrm{O}_{3} \%$ & Feldspar \% \\
\hline 2.0 & 67.62 & 13.80 & 0.140 & 66.24 \\
$2.0-3.0$ & 65.91 & 15.30 & 0.120 & 75.86 \\
$4.0-4.5$ & 68.46 & 12.80 & 0.145 & 61.44 \\
\hline
\end{tabular}

Table 5. Effect of cationic collector dose on the improvement of the flotation process.

\begin{tabular}{ccccc}
\hline Dose, $\mathrm{Kg} / \mathrm{t}$ & ${\mathrm{Total} \mathrm{SiO}_{2} \%}$ & $\mathrm{Al}_{2} \mathrm{O}_{3} \%$ & $\mathrm{Fe}_{2} \mathrm{O}_{3} \%$ & Feldspar \% \\
\hline 0.250 & 65.91 & 15.30 & 0.120 & 75.86 \\
0.291 & 65.63 & 15.92 & 0.118 & 76.42 \\
0.332 & 69.16 & 15.50 & 0.123 & 74.42 \\
0.400 & 67.08 & 15.45 & 0.123 & 74.14 \\
\hline
\end{tabular}

Table 6. Effect of HF dose on the Improvement of the flotation process.

\begin{tabular}{cccccc}
\hline HF Dose, kg/t & Wt., $\%$ & Total $\mathrm{SiO}_{2} \%$ & $\mathrm{Al}_{2} \mathrm{O}_{3} \%$ & $\mathrm{Fe}_{2} \mathrm{O}_{3} \%$ & Feldspar \% \\
\hline 1.30 & 91.87 & 65.63 & 15.92 & 0.118 & 76.42 \\
2.60 & 75.46 & 68.79 & 17.83 & 0.120 & 85.58 \\
5.20 & 64.89 & 65.30 & 18.65 & 0.119 & 89.52 \\
\hline
\end{tabular}

\subsection{Pilot Plant Operations and Materials Metallurgical Balance Calculations}

Complete chemical analyses of the pilot plant feldspar concentrates of both samples is shown in Table 8 and the metallurgical balance of the whole operations is depicted in Table 9. Concentrates having $78.62 \%$ and $87.02 \%$ feldspar minerals were obtained with Road Ashaab feldspar samples, 1 and 2 respectively at an overall recovery of $80.74 \%$ and $92.8 \%$. Both products satisfy the international specifications for ceramics industries. They are rich in potash, moderate in alumina and have a minimum content of iron oxide and free silica impurities.

\section{Conclusions}

The amenability of two feldspar samples to a differential flotation process including both anionic and cationic 
Table 7. Complete chemical analysis of final feldspar samples concentrates.

\begin{tabular}{ccc}
\hline Sample Constituents, \% & Sample No.1 & Sample No. II \\
\hline $\mathrm{Total} \mathrm{SiO}_{2}$ & 65.30 & 67.86 \\
$\mathrm{Al}_{2} \mathrm{O}_{3}$ & 18.65 & 16.84 \\
$\mathrm{Fe}_{2} \mathrm{O}_{3}$ & 0.119 & 0.127 \\
$\mathrm{CaO}$ & 2.00 & 1.50 \\
$\mathrm{MgO}$ & 0.25 & 0.20 \\
$\mathrm{Na}_{2} \mathrm{O}$ & 2.30 & 2.20 \\
$\mathrm{~K}_{2} \mathrm{O}$ & 10.97 & 10.92 \\
L.O.I. & 0.23 & 0.30 \\
\hline
\end{tabular}

Table 8. Complete chemical analysis of pilot plant final feldspar samples concentrates.

\begin{tabular}{ccc}
\hline Sample Constituents, \% & Sample No. 1 & Sample No. II \\
\hline $\mathrm{Total} \mathrm{SiO}_{2}$ & 67.95 & 66.41 \\
$\mathrm{Al}_{2} \mathrm{O}_{3}$ & 16.38 & 18.13 \\
$\mathrm{Fe}_{2} \mathrm{O}_{3}$ & 0.13 & 0.15 \\
$\mathrm{CaO}$ & 1.57 & 2.03 \\
$\mathrm{MgO}$ & 0.20 & 0.26 \\
$\mathrm{Na}_{2} \mathrm{O}$ & 2.09 & 2.30 \\
$\mathrm{~K}_{2} \mathrm{O}$ & 10.91 & 10.71 \\
L.O.I. & 0.29 & 0.30 \\
Feldspar Mineral & 78.62 & 87.02 \\
\hline
\end{tabular}

Table 9. Metallurgical balance of pilot plant beneficiation operations of feldspar samples.

\begin{tabular}{|c|c|c|c|c|c|c|}
\hline \multirow{2}{*}{ Pilot Plant Product } & \multicolumn{3}{|c|}{ Sample I } & \multicolumn{3}{|c|}{ Sample II } \\
\hline & Flow Rate, Kg/h & $\mathrm{Wt} \%$ & $\mathrm{Fe}_{2} \mathrm{O}_{3} \%$ & Flow Rate, Kg/h & $\mathrm{Wt} \%$ & $\mathrm{Fe}_{2} \mathrm{O}_{3} \%$ \\
\hline Feed & 200.00 & 100.00 & 0.225 & 200.00 & 100.00 & 0.53 \\
\hline Spiral Classifier O.F & 23.00 & 11.50 & & 11.00 & 10.50 & \\
\hline Hydro-classifier O.F. & 8.00 & 4.50 & & 5.00 & 2.50 & \\
\hline $\begin{array}{l}\text { Tailings (Anionic \& cationic } \\
\text { Flotation Process) }\end{array}$ & 51.00 & 25.50 & & & 23.00 & \\
\hline Final Concentrate & 118.00 & 59.00 & 0.130 & 128.00 & 64.00 & 0.143 \\
\hline
\end{tabular}

circuits was investigated on laboratory and pilot plant scales. The ores are pegmatites belonging to the alkali feldspar granite type, mostly microcline and orthoclase coarse-grained rocks. Quartz, as the main gangue mineral, occurs in either free grains or as veins intercalating the feldspar crystals or intermingled with them. Iron, as the other impurity, is found in different forms as free magnetite embedded in the feldspar crystals as microcrystalline crystals or as magnetite filling cracks in the feldspar.

The secondary crushed ores were wet ground to $-0.25 \mathrm{~mm}$ in a ball mill in closed circuit with the screen, then deslimed to reject the slimes less than $0.03 \mathrm{~mm}$ before subjected to flotation. This was carried out through a reverse anionic circuit followed by a direct cationic one. A locally produced dodecyl benzene sulphonic acid was employed as an iron oxide collector at $\mathrm{pH} 3$ in the former process. A small dose of rice bran oil $(0.75 \mathrm{~kg} / \mathrm{t}) \mathrm{in}$ kerosene that was added to the collector as a foam conditioner resulted in a remarkable decrease in its consumption from $7.0 \mathrm{~kg} / \mathrm{t}$ to $1.5 \mathrm{~kg} / \mathrm{t}$. Cationic flotation of feldspar from this pre-concentrate was then carried out using 
a locally produced amine at $\mathrm{pH} 2.5$ - 3.0 in presence of $\mathrm{HF}$ as a free silica depressant and a feldspar activator. Final feldspar concentrates assaying $80.8 \%$ to $89.5 \%$ feldspar mineral, $0.119 \%-0.127 \% \mathrm{Fe}_{2} \mathrm{O}_{3}$ and $16.84 \%-$ $18.65 \% \mathrm{Al}_{2} \mathrm{O}_{3}$ that satisfy the requirements of the International Ceramic Society.

A metallurgical balance of the whole operations and complete chemical analyses of products were shown.

\section{References}

[1] Kogel, J.E., Trivedi, N.C., Barker, J.M. and Krukowski, S.T. (2006) Industrial Minerals \& Rocks, Commodities, Markets and Uses. 7th Edition Book, Society for Mining, Metallurgy and Exploration, (SME).

[2] Shimoilzaka, J.K., Nakatsaka and Katayanagi, T. (1976) In: Weies, A., Ed., World Mining and Materials Technology, Port City Press, Baltimore, 423.

[3] Demir, C., Abramov, A.A. and Celik, M.S. (2000) Flotation Separation of Na-Feldspar from K-Feldspar by Monovalent Salts. Minerals Engineering, Cape Town.

[4] Katayanagi, A. (1978) Ceram Journal, 8, 58.

[5] Gaied, M.E. and Gallala, W. (2015) Beneficiation of Feldspar Ores for Application in the Ceramic Industry: Influence of Composition on the Physical Characterization. Arabian Journal of Chemistry, 8, 186. http://dx.doi.org/10.1016/j.arabjc.2011.04.011

[6] Gulgonul, I., Karaguzel, C. and Celik, M.S. (2008) Surface vs. Bulk Analyses of Various Feldspars and Their Significance to Flotation. International Journal of Mineral Processing, 86, 68. http://dx.doi.org/10.1016/j.minpro.2007.11.001

[7] Orhan, E.C. and Bayraktar, I. (2006) Amine-Oleate Interactions in Feldspar Flotation. Minerals Engineering, 19, 48. http://dx.doi.org/10.1016/j.mineng.2005.06.001

[8] Bayat, O., Arslan, V. and Cebeci, Y. (2006) Combined Application of Different Collectors in the Flotation Concentration of Turkish Feldspars. Minerals Engineering, 19, 98. http://dx.doi.org/10.1016/j.mineng.2005.06.015

[9] Heyes, G.W., Allan, G.C., Brenkard, W.I. and Sparrow, G.I. (2012) Review of Flotation of Feldspar. Mineral Processing and Extractive Metallurgy (Translations of the Institution of Mining \& Metallurgy, Section C), 121.

[10] Vidyadhar, A., Hanumantha Rao, K. and Forsberg, K.S.E. (2002) Separation of Feldspar from Quartz: Mechanism of Mixed Cationic/Anionic Collector Adsorption on Minerals and Flotation Selectivity. Minerals and Metallurgical Processing, 19, 128.

[11] Diaz, A.A., Castre, J.T., Bastante, F.G. and Fernandez, M.A. (2013) Effect of Flotation Variables on Feldspathic Sand Concentration. Dyna Journal, 81, 132.

[12] Demir, C. (2010) Selective Separation of Na and K-Feldspar from Weathered Granites by Flotation in HF Medium. Ceramics-Silikaty, 54, 60-64. 